\title{
MENUJU SUSTAINABILITY DENGAN TRI HITA KARANA (SEBUAH STUDI INTERPRETIF PADA MASYARAKAT BALI)
}

\author{
Hasudungan Hutasoit ${ }^{1}$ \\ Universitas 17 Agustus 1945 Jakarta \\ sudung h@yahoo.com \\ Redaktur $\mathrm{Wau}^{2}$ \\ Universitas 17 Agustus 1945 Jakarta \\ redakturwau@gmail.com
}

\begin{abstract}
This article aims to provide an understanding of the meaning of the local wisdom of Tri Hita Karana (THK) of Bali as a concept to achieve sustainability. THK relevant issues was appointed amid the deterioration of the quality of life of mankind as a result of excessive exploitation of nature. That downturn has also hit Indonesia due to the hegemony of positivist paradigm and tendencies attributing a materialistic rationality. Indeed in THK there are values that ought to be executed to achieve sustainability. If the corporate world to apply to achieve Triple Bottom Line sustainability, Balinese prove THK has been keeping sustainable remains until now Bali. The difference of the two is on the concept of profit (profit) and Lord's (parahyangan). This research combines the data gathering methods Cresswel, ethnographic interviews Spradley and qualitative paradigm analysis interpretivisme.
\end{abstract}

Keywords: Interpretivisme, Tri Hita Karana, Sustainability and Antropological Approach.

\begin{abstract}
ABSTRAK
Artikel ini bertujuan untuk memberikan pemahaman atas makna kearifan lokal Tri Hita Karana (THK) dari Bali sebagai konsep untuk mencapai sustainability. THK relevan diangkat sebagai isu di tengah kemerosotan kualitas hidup manusia sebagai akibat eksploitasi berlebihan terhadap alam. Kemerosotan itu juga melanda Indonesia dikarenakan hegemoni paradigma positivis dan kecenderungan menganggungkan rasionalitas materialistis. Sesungguhnya di dalam THK terdapat nilai-nilai yang patut dijalankan untuk mencapai sustainability. Jika dunia usaha menerapkan Triple Bottom Line untuk mencapai sustainability, masyarakat Bali membuktikan THK telah menjaga Bali tetap berkelanjutan sampai kini. Perbedaan keduanya adalah pada konsep laba (profit) dan ke-Tuhan-an (parahyangan). Penelitian ini mengkombinasikan metode pengumpulan data Cresswel, wawancara etnografi Spradley dan analisis paradigma kualitatif interpretivisme.
\end{abstract}

Kata Kunci: Interpretivisme, Tri Hita Karana, Sustainability, Pendekatan Antropologis. 


\section{PENDAHULUAN}

Manusia dari semulanya sudah tergantung dengan alam dan sesamanya. Manusia tidak bisa hidup sendiri, tidak bisa hidup tanpa sumber daya alam. Oleh karena itu manusia kemudian membentuk institusi sosial dan mengelola (ekonomisasi) sumber daya alam guna memenuhi kebutuhannya (Malinowski, 1960; Polanyi, 1964 dalam Carrier, 2005). Sumber daya alam yang terbatas tersebut seringkali tidak cukup untuk memenuhi kebutuhan manusia, karena sifat manusia yang tiada puaspuasnya dalam mengumpulkan harta (kapitalisme).

Perhatian manusia terhadap kelestarian lingkungan akhir-akhir ini semakin intens. Hal tersebut timbul sebagai respon manusia atas dampakdampak buruk eksploitasi berlebihan terhadap alam. Baru-baru ini kita menyaksikan betapa besarnya kerugian materil dan moril, bahkan korban jiwa manusia akibat bencana asap yang mengepung Sumatera dan Kalimantan selama berbulan-bulan. Asap tersebut sebagai akibat pembakaran lahan untuk keperluan menanam kelapa sawit. Lagilagi kita harus menerima konsekuensi ulah manusia itu sendiri.

Gerakan penyelamatan lingkungan yang terdengar gaungnya dalam ruang publik biasanya berasal dari dunia internasional (Barat). Dapat kita sebutkan satu yang terkenal adalah gerakan Green Peace. Gerakan ini sangat demonstratif menentang eksploitasi berlebihan atas alam dan mendapat liputan yang luas. Sementara gerakan-gerakan lokal tidak terdengar gaungnya, seolah-olah tidak ada. Padahal kalau kita berkunjung ke daerah-daerah di pelosok tanah air, kita dapat menemukan local wisdom (kearifan lokal) yang berkaitan langsung dengan kelestarian alam. Ambil contoh jika kita berkunjung ke desa tradisional
Baduy di Banten atau desa Cangkuang di Garut. Kita dapat merasakan suasana yang berbeda, kehidupan seperti melambat, tidak ada yang memburu, semua seirama alam, semua berjalan berharmoni dengan alam sekitar. Kearifan lokal seperti itu tersebar di Nusantara, tapi tidak banyak yang terangkat ke permukaan, luput dari perhatian.

Arus informasi yang begitu deras telah menggempur sisi-sisi kepribadian bangsa kita. Berbagai label-label modernis menjauhkan kita dari nilainilai lokal. Generasi bangsa dikotakkotakkan dengan istilah teknis hasil bentukan negara lain. Bisa kita sebutkan istilah globalisasi, metroseksual, generasi $\mathrm{Y}$, generasi $\mathrm{Z}$, dan lain-lain yang menjadi kartu akses ke dalam ruang kepribadian bangsa, menelanjangi kita dari pakaian budaya lokal lalu memakai baju-baju asing. Orang Indonesia sebahagian telah terputus dari sejarahnya sendiri, menjadi manusia yang "baru" dengan budaya yang baru, mengasosiasikan dirinya dengan labellabel bentukan pengetahuan asing. Istilah-istilah bentukan asing itu tak ubahnya seperti kuda troya, yang apabila kita tidak waspada meneliti isinya, maka nilai-nilai asing yang dibawanya akan mudah masuk ke dalam bangunan budaya kita lalu memporakporandakan, meluluhlantakkannya sebelum kita sempat menyadarinya.

Akuntansi Indonesia tak luput dari terpaan arus globalisasi. Pendidikan, kode etik dan standar akuntansi Indonesia mengacu kepada akuntansi Barat (Mulawarman, 2008; Kamayanti, 2013). Entah disadari atau tidak, semangat pasar bebas yang berada di jantung kapitalisme telah terpompa dan mengalir memenuhi sumsum dan sendisendi akuntansi Indonesia, sejak disemaikan di dunia pendidikan hingga dipraktikkan di lapangan. Apakah semangat pasar bebas itu? Tiada lain 
daripada keuntungan (profit) yang maksimal, yang menuntut efisiensi yang maksimal pula. Entitas yang di dalam rohnya telah bersemayam jiwa pasar bebas akan mengutamakan keuntungan daripada yang lain, mengutamakan rasionalitas yang berakibat pada dehumanisasi. Semangat yang terpompa di darah akuntasi adalah semangat kapitalistis, individualistis, dan materialistis. Triyuwono (2010) mengatakan bahwa akuntansi modern telah terjebak dalam jaring materialistis karena berorientasi kepada laba sebagai bottom line.

Usaha membawa akuntansi untuk lebih manusiawi sudah dilakukan sejak lama. Usaha itu dimulai dari penelitian akuntansi dengan memasukkannya ke dalam bidang sosial. Paradigma yang digunakan tidak semata-mata fungsionalisme lagi, tetapi juga menggunakan paradigma interpretativisme. Paradigma yang menekankan kepada pemahaman (verstehen). Di Indonesia sendiri, penggunaan multiparadigma sudah mulai terbuka. Sukoharsono (2010) pada Pidato Pengukuhan Jabatan Guru Besar Dalam Ilmu Akuntansi Sosial dan Lingkungan Fakultas Universitas Brawijaya - Malang, menyebutkan adanya metamorfosis akuntansi menuju Akuntansi Sosial dan Lingkungan, untuk mencapai sustainabilitas dengan dimensi spiritualitas. Lebih jauh Sukoharsono dengan pemikiran postmodernisme menerangkan bahwa akuntansi tidak melulu lagi hanya ilmu kalkulasi angkaangka, tetapi merupakan ilmu sosial dengan diskursus partisipasi kontekstual, naratif dan transendental. Intelektualitas termasuk akuntansi yang secara tradisional mengedepankan rasionalitas objektif, kini bergerak dengan melibatkan spiritualitas dan subjektivitas..

\section{Menerangkan Eksploitasi Global dan Tragedi Kultur dengan Konsep McDonaldisasi dari Ritzer}

Modernitas merupakan sebuah fase dimana uang menjadi sangat dominan. Menurut Marx (1964) dalam Ritzer \& Goodman (2008), modernitas ditentukan oleh ekonomi kapitalis. Modernitas pada satu sisi telah membawa masyarakat ke dalam kemajuan kapitalisme. Di sisi lain, sistem ekonomi kapitalis menimbulkan banyak kerusakan seperti alienasi, eksploitasi dan sebagainya. Simmel (1903) mengatakan bahwa modernisasi memberikan keuntungan bagi manusia, dimana melalui modernisasi manusia mampu mengungkapkan berbagai potensi yang belum terungkapkan selama masa pramodern. Dalam masyarakat modern, uang sangat berpengaruh. Uang inilah yang menjadi sumber permasalahan sosial yaitu alienasi. Masalah alienasi melahirkan "tragedi kultur", melebarnya jurang pemisah antara kultur objektif dan kultur subjektif. Sedangkan seorang bijak bernama Santo Paulus telah mengatakan bahwa cinta akan uang adalah akar dari segala kejahatan yang menyebabkan seseorang menyimpang dari iman dan menyiksa dirinya sendiri.

Modernitas juga telah melahirkan globalisasi. Globalisasi menurut Beck (2000) adalah proses yang melaluinya negara yang berdaulat dimasuki dan dilemahkan oleh aktor-aktor transnasional dengan berbagai macam prospek kekuasaan, orientasi, identitas dan jaringan. Proses transnasional ini bukan hanya ekonomi, tetapi juga melibatkan ekologi, kultur, politik, dan masyarakat sipil. Globalisasi juga dipahami sebagai sesuatu yang berasal dari Barat dan Amerika Serikat, yaitu proses menjalarnya sistem kapitalis ke penjuru dunia. Menurut Kernell (2002) dalam Ritzer \& Goodman (2008) globalisasi melibatkan pasar kapitalis 
dan seperangkat relasi sosial dan aliran komoditas, kapital, teknologi, ide-ide, bentuk-bentuk kultur, dan penduduk yang melewati batas-batas nasional via jaringan global.

Dominasi ekonomi dan munculnya hegemoni pasar dunia kapitalis yang memandang segala sesuatu dengan paradigma fungsionalisme diterangkan dalam buku Ritzer, yang disebutnya McDonaldisasi. Ritzer (1995) memaparkan bahwa wabah McDonald sesungguhnya berakar dari ide rasionalitas, yaitu menggunakan rasionalitas formal untuk menentukan keuntungan maksimal. Dalam semangat ekonomi (pasar bebas), yang bersemayam di jantung kapitalisme, tujuan utama adalah mengejar keuntungan yang maksimal. Dalam kerangka ini McDonald menciptakan hirarki dan tanggung jawab kerja terstuktur dalam organisasinya. Masingmasing kerja didefinisikan sesuai fungsinya untuk mencapai tujuan perusahaan. Prinsip kerja McDonald adalah efisiensi, yang semuanya diukur dengan angka (kuantitas).

Segera saja prinsip ini ditiru oleh perusahaan-perusahaan lain. Restoranrestoran cepat saji tumbuh dengan pesat. Perusahaan jasa lainnya juga meniru prinsip kerja McDonald, rumah sakit, dokter, media massa, bahkan jasa perbankan dengan Anjungan Tunai Mandiri (ATM) dan kartu-kartunya. Di tempat-tempat yang meniru McDonald, pembeli produk dan jasa hanya bisa memesan sesuai dengan pilihan yang tersedia. Bayangkan anda berada di restoran McDonald, tentu anda tidak bisa meminta "jangan banyak garamnya ya..." seperti anda memesan nasi goreng di warung biasa. Demikian di dalam mesin ATM sudah ada menu-menu yang harus dipilih, dan pengguna terbatas hanya pada menu-menu tersebut.
Spirit McDonaldisasi juga ditanamkan kepada manusia sesuai fungsi kerjanya masing-masing. Ketika anda berkunjung ke sebuah hotel, anda akan mendapatkan senyuman yang sama dari semua staf yang anda temui. Semakin mahal hotelnya, semua staf yang anda temui hampir dipastikan akan tersenyum selalu. Ketika anda berkunjung ke sebuah bank, senyum sapa yang ramah secara mekanis akan meluncur dari para stafnya. Semua bank melakukan hal yang sama. Ketika anda menelepon call center sebuah perusahaan, hampir dapat dipastikan anda akan mendapat pertanyaan pembuka dan pernyataan penutup yang sama. Semua terdengar sangat mekanis dan ingin cepat-cepat selesai. Manusia berlaku layaknya mesin-mesin robot. Semua ingin cepat, semua ingin instan, semua ingin standar, semua sama satu warna. Tidak ada sapa ala Sunda, Batak, Jawa, Bali, Nias dan lain-lain. Hidup menjadi kering, homogen dan tak ada sapa tulus.

McDonaldisasi telah menjadi ironi bagi manusia yang berbudaya, bagi manusia sebagai makhluk sosial, sebab mereka kini serupa robot dengan ekspresi sesuai program yang dimasukkan di prosesornya. Telah terjadi dehumanisasi. Padahal sesungguhnya manusia hidup bukan hanya untuk alasan rasionalitas, tetapi manusia memiliki rasa - hati, termasuk cita-cita spiritual yang justru mungkin bernilai utama dalam hidupnya daripada hanya urusan efisiensi belaka. Seharusnya manusia membutuhkan intersubjektifitas, membutuhkan komunikasi dengan sesamanya, karena manusia bukan robot yang bisa hidup hanya dengan daya listrik, atau hewan yang hanya perlu makanan.

Dehumanisasi merupakan bentuk irasionalitas dari rasionalitas itu sendiri. Antrian panjang di depan kasir outletoutlet makanan cepat saji dan di ATM 
merupakan contoh sumber stress manusia-manusia modern sebagai ekses dari McDonaldisasi. Intensifikasi produksi bahan baku dengan berbagai teknologi dilakukan guna memenuhi permintaan, acapkali mengabaikan kualitas dan kesehatan manusia yang mengkonsumsinya sekaligus memperkosa sumber daya alam. Penggunaan mesin-mesin berkecepatan tinggi telah mendorong percepatan kerusakan lingkungan. Mesin-mesin gergaji dengan cepat menggunduli pohon sementara truk-truk besar sudah siap mengantarkannya ke dalam pabrik. Kesemuanya itu kini memberikan dampak yang irasional dalam kehidupan umat manusia. Disharmoni antara manusia dengan alam semakin menjadijadi. Bencana akibat disharmoni itu telah menimbulkan banyak kerugian materil bahkan menelan korban jiwa. Itulah tragedi budaya bagi manusia.

\section{Konsep Triple Bottom Line sebagai Respon dari Manusia Modern}

Triple bottom line (TBL) merupakan gagasan yang berkenaan dengan keberlanjutan (sustainability) atau kelestarian lingkungan. TBL dan sustainability sering digunakan secara bergantian untuk maksud yang sama. TBL sebagai gagasan tentang sustainability pertama sekali digunakan oleh Elkington (1997). Namun, asal-usul gagasan tersebut kemungkinan sudah ada sejak sekira 130 tahun lampau. yang dikenal sebagai spaceship earth (George, 1879/2009). Gagasan tentang pelestarian lingkungan semakin mengemuka seiring dengan munculnya istilah "pembangunan yang berkelanjutan" dalam sebuah laporan "Brundtland Report" tahun 1987. Laporan ini memberikan definisi pembangunan berkelanjuntan sebagai pembangunan yang memenuhi kebutuhan generasi sekarang tanpa membahayakan (mengganggu) kemampuan generasi mendatang untuk memenuhi kebutuhan mereka (Brundtland, 1987 dalam Alhaddi, 2015).

TBL menyediakan sebuah kerangka kerja untuk mengukur kinerja sebuah bisnis dan keberhasilan sebuah organisasi dengan menggunakan tiga parameter: ekonomi, sosial, dan lingkungan. Tiga parameter ini dalam literature Elkington (1997) disebut sebagai profit, people, dan planet respectively (laba, manusia, lingkungan). Elkington kemudian menderivasi TBL ke dalam konsep corporate social responsibility (CSR) atau tanggung jawab sosial perusahaan.

CSR berkembang pesat sejak 1980-an hingga 1990-an sebagai reaksi dan suara keprihatinan dari organisasi masyarakat sipil dan jaringan tingkat global untuk meningkatkan perilaku etis, fairness dan responsibilitas korporasi yang tidak hanya terbatas pada korporasi, tetapi juga pada para pemangku kepentingan (stakeholder) dan masyarakat sekitar wilayah kerja dan operasinya. CSR timbul sejak era dimana kesadaran akan sustainability perusahaan jangka panjang dianggap lebih penting daripada sekedar profitability. CSR dijalankan melampau kepatuhan kepada hukum (beyond compliance to law). Dalam gagasan tersebut, perusahaan tidak lagi diharapkan hanya berpijak pada aspek ekonomi yang direfleksikan dalam kondisi finansialnya saja, namun juga harus memperhatikan aspek sosial dan lingkungannya. Keberlanjutan perusahaan akan terjamin apabila korporasi juga turut memperhatikan dimensi sosial dan lingkungan hidup.

TBL dapat digambarkan dalam bentuk segitiga yang meghubungkan tiga bottom lines yang menjadi parameter keberhasilan sebuah perusahaan 


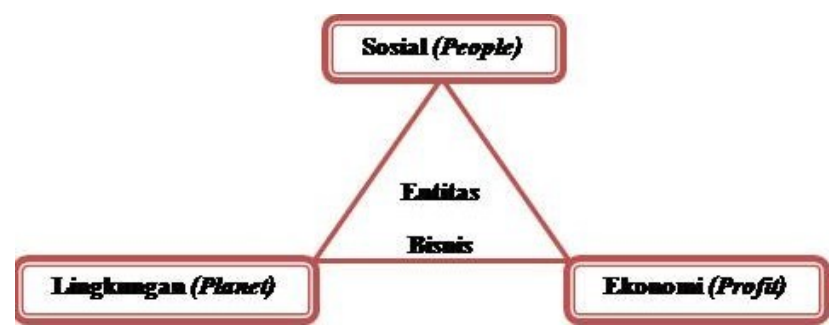

Gambar 1 Hubungan Garis Segitiga Triple Bottom Line Sumber: Elkington (1997)

\section{Bertahan dengan Spiritualitas dan Budaya Bangsa}

Konsep budaya (culture) bersamaan dengan masyarakat (society) merupakan salah satu konsep yang paling luas digunakan dalam sosiologi. Budaya mengandung nilai yang dipegang masyarakat, norma yang mereka ikuti, dan benda-benda yang mereka ciptakan. Nilai merupakan sesuatu yang abstrak, norma merupakan prinsip-prinsip atau aturan yang diharapkan dipatuhi oleh anggota masyarakat. Norma mewakili apa yang boleh dan tidak boleh dilakukan dalam kehidupan sosial (Giddens, 2009).

Terma budaya dalam kehidupan sehari-hari seringkali dianggap sama dengan seni, literatur, musik, atau lukisan. Tapi dalam sosiologi menurut Giddens, budaya masih lebih luas. Budaya merujuk kepada cara hidup (way of life) dari anggota masyarakat atau sekelompok masyarakat. Termasuk di dalamnya cara berbusana, kehidupan pernikahan dan keluarganya, rupa pekerjaannya, upacara religi, dan tujuan hidupnya. Budaya mencakup alat-alat yang dibuat manusia seperti cawan, panah, pabrik, mesin, komputer, buku, dan lain-lain. Koentjaraningrat (2005) menekankan proses belajar dan menggunakan akal. Dia mengatakan kebudayaan adalah segala hal yang dimiliki oleh manusia, yang diperolehnya dengan belajar dan menggunakan akalnya.
Budaya dapat dibedakan dengan masyarakat, tetapi keduanya memiliki hubungan yang dekat dalam konsepnya. Masyarakat merupakan interrelasi yang menghubungkan individu-individu bersama. Budaya tidak akan eksis tanpa masyarakat, demikian sebaliknya masyarakat tidak eksis tanpa budaya. Tanpa budaya, kita bukanlah "manusia" yang utuh. Kita tidak akan memiliki bahasa untuk mengekspresikan diri, tidak ada kesadaran diri, dan kemampuan kita untuk berpikir akan sangat minim.

Budaya sering juga diterjemahkan sebagai adat istiadat. Kata "adat" berasal dari bahasa Arab, yaitu "ậda" yang berarti datang kembali. Adat adalah sesuatu yang datang kembali berulangulang dan menjadi satu kebiasaan (Geertz, 1983 dalam Nainggolan, 2014). Kebiasaan yang dilakukan terus menerus oleh masyarakat dan menjadi hukum bagi mereka. Lebih jauh Geertz (1983) sebagaimana dikutip Nainggolan (2014) adat adalah suatu cara pikir suatu bangsa (masyarakat) dimana mereka membentuk dunianya (weltanshaung). Dengan adat, suatu masyarakat mengatur dirinya dalam kesusilaan dengan maksud mencapai harmoni spiritual, dimana kedamaian menyeluruh dicapai dengan adanya kesepakatan sosial bersama.

Semangat modernisasi dan globalisasi sesungguhnya merupakan fakta empiris yang sudah ada di rumah 
kita. Untuk tidak tergilas olehnya, diperlukan pertahanan diri yang kuat. Sehingga bangsa Indonesia bisa berjalan sejajar dengan bangsa lain, tidak dependen tetapi interdependen (Swasono, 2004). Ide-ide yang datangnya dari luar semestinya diterima dengan sikap kritis. Diambil yang cocok dengan kepribadian Indonesia, yang tidak cocok diabaikan. Nilai-nilai yang dimiliki sendiri perlu diperkuat, dikonstruksi menjadi pengetahuan bersama, membuat yang lokal menjadi global.

Modernitas telah menghapuskan sekat ruang-ruang lokal menjadi satu ruang global yang merupakan arena pertarungan budaya. Ruang semakin menjadi "phantasmagoric" artinya tempat terjadinya peristiwa sepenuhnya ditembus dan ditentukan oleh pengaruh sosial dari tempat yang jauh (Giddens, 1990). Dengan kondisi demikian itu, tentu bangsa Indonesia berada dalam satu ruang global dengan segala kemampuan yang dimilikinya. Pertarungan budaya dalam ruang tersebut akan berlangsung dan dimenangkan oleh pihak-pihak yang kuat. Seumpama pertarungan tinju, bangsa Indonesia tidak cukup dengan pertahanan double cover dan foot step yang menghindar, namun pertahanan terbaik adalah menyerang. Dalam hal ini, globalisasi merupakan peluang menyerang (membuat yang lokal menjadi global). Nilai-nilai lokal Indonesia ditampilkan sebagai sesuatu yang berharga dan menjadi nilai-nilai yang menginspirasi masyarakat dunia.

Spritualitas dan budaya merupakan benteng kokoh yang bisa menahan arus modernisasi dan globalisasi. Di Indonesia, spritualitas dan budaya merupakan dua hal yang menyatu. Masyarakat menjalankan budayanya dalam bingkai agama, sementara agama masuk melalui budaya. Mereka adalah sebuah koin dengan sisi agama dan sisi budaya. Kekayaan warisan budaya bangsa yang sudah mendapat pencerahan agama merupakan modal untuk membangun bangsa.

Kekayaan warisan budaya Indonesia tercermin dalam semboyan Bhineka Tunggal Ika. Dari Sabang sampai Merauke, ragam budaya dapat dijumpai. Warisan budaya merupakan kekuatan yang hebat. Memiliki akar yang dalam dan hidup yang panjang, bertahan dari generasi ke generasi, diwariskan turun temurun bagi generasi yang peduli. Atas dasar itulah peneliti termotivasi untuk meneliti salah satu warisan budaya Indonesia yang lahir dan hidup di pulau dewata Bali, yakni prinsip Tri Hita Karana.

Tri Hita Karana (THK) adalah tiga penyebab kebahagiaan yang utuh di dalam kehidupan manusia (Utama, 2008). Jika tujuan setiap entitas usaha adalah kemakmuran eknomis, sebaliknya dengan THK tujuannya adalah mencapai kebahagiaan yang utuh sebagai manusia. Sementara itu akhirakhir ini ada semacam perjumpaan ide antara THK dengan dunia usaha dengan berkembangnya gagasan untuk mencapai sustainability (kesinambungan, kelestarian alam). Gagasan tersebut oleh Elkington (1997) diberi nama sebagai Triple Bottom Line (TBL) dengan dimensi yang terdiri dari profit (laba), people (manusia), dan planet respectively (pemeliharaan atas alam).

Dengan latar belakang tersebut,
penelitian ini bertujuan untuk
memahami realitas sosial yang
dipraktekkan oleh masyarakat Hindu
Bali. Pemahaman tersebut akan
diungkapkan sebagai jalan alternatif
bagi pembangunan berkelanjutan dengan
judul "Menuju Sustainability dengan
Tri Hita Karana".




\section{METODE PENELITIAN}

\section{Asumsi \\ Paradigmatik: \\ Interpretivisme}

Setiap peneliti selalu menggunakan asumsi paradigmatik dalam penelitiannya. Asumsi penelitian adalah kondisi yang ditetapkan sebagai suatu kebenaran, yang berfungsi sebagai konteks sekaligus pembatasan bagi suatu penelitian. Dalam pendekatan penelitian, asumsi-asumsi dasarnya merupakan jabaran dari paradigma, sehingga disebut juga sebagai asumsi-asumsi paradigmatik (Sitorus, 2015). Asumsiasumsi penelitian terdiri dari asumsi ontologi, epistemologi dan asumsi tentang human nature (Burrel \& Morgan, 1979). Eriksson \& Kovalainen (2008) menyebutkan ada lima konsep kunci dari sains filsafat: ontologi, epistemologi, metodologi, metode dan paradigma. Salim (2006) menyebutkan lima dimensi dalam pengembangan paradigma ilmu yaitu berupa lima pertanyaan filosofis dan metodologis dalam penemuan ilmu pengetahuan, yaitu: dimensi ontologis, epistemologis, aksiologis, retoris dan metodologis.

Asumsi ontologis penelitian ini meyakini bahwa realitas merupakan hasil konstruksi individu yang terlibat dalam penelitian. Guna mendapatkan pengetahuan (epistemologis) maka harus ada interaksi dengan situs penelitian dan mengurangi jarak dengan tineliti. Peneliti meyakini bahwa manusia (human nature) memiliki kehendak bebas, menguasai, mengendalikan dan menciptakan lingkungannya (volunterisme). Peneliti memposisikan (aksiologis) adanya nilai dari peneliti (value laden) yang mempengaruhi penelitiannya dan menyampaikan laporan penelitian dengan bahasa (retoris) yang personal. Creswell (1994) menjelaskan bahwa dimensi asumsi itu berkonsekuensi kepada desain metodologi penelitian secara keseluruhan.
Penelitian ini merupakan penelitian budaya, dengan demikian merupakan penelitian sosial. Penelitian sosial bertujuan untuk menafsirkan dan memahami dunia sosial (Walliman, 2006). Oleh karena tujuannya adalah untuk memahami, maka paradigma yang digunakan adalah kualitatif interpretivisme. Interpretivisme adalah pendekatan dalam penelitian sains sosial yang menolak ide positivist - bahwa metode penelitian yang sama dapat digunakan untuk mempelajari perilaku manusia juga untuk mempelajari sifatsifat kimia dan fisika. Interpretivist memberikan argumen bahwa ketika mempelajari perubahan pada benda logam misalnya, maka hal-hal yang mempengarunginya adalah lingkungan alam seperti suhu. Sementara manusia menjadi bagian dari lingkungannya sendiri, dan dipengaruhi persepsi subjektifnya mengenai lingkungannya, realitas subjektifnya sendiri. Kita tak perlu menghiraukan kesan subjektif dari sebatang logam, tetapi jika kita ingin sepenuhnya memahami perilaku seorang remaja, kita harus memahami cara pandangnya terhadap lingkungan sekitarnya. Dus, bagi interpretivist, apa makna dunia bagi seseorang atau sekelompok orang yang sedang dipelajari, memerlukan pedekatan yang tepat. Interpretivist memilih metode kualitatif seperti studi kasus (case study), wawancara (interview study), dan pengamatan (observation) karena metode ini merupakan cara yang lebih baik untuk memahami bagaimana manusia memaknai dunianya (Willis, 2007).

\section{Etnografi Sebagai Metode Penelitian}

Penelitian kualitatif ini berfokus meneliti satu sistem yang hidup dalam masyarakat Bali, yaitu Tri Hita Karana. Penelitian ini berangkat dari pertanyaan apa makna budaya (dalam hal ini Tri Hita Karana) yang hidup dalam masyarakat Bali. Sebagai konsekuensi dari asumsi paradigmatik yang sudah 
ditetapkan dalam penelitian ini, maka metode yang dipilih juga haruslah tepat. Untuk memahami budaya Bali ini digunakan metode etnografi. Menurut Ihromi (1996), etnografi adalah cabang dari antropologi budaya yang menyibukkan diri dengan pelukisanpelukisan kebiasaan-kebiasaan dalam berbagai masyarakat. Sedangkan antropologi adalah ilmu yang mencoba menelaah dan memahami sifat-sifat manusia.

Metode ini dapat mendeskripsikan secara detail teori-teori penduduk asli yang telah diuji dalam situasi kehidupan nyata selama beberapa generasi. Etnografi merupakan metode penelitian kualitatif yang bertujuan untuk menjelaskan, menganalisa, dan menafsirkan kebudayaan, memahami cara hidup orang lain dari sudut pandang mereka (Malinowski, 1922 dalam Spradley, 1980; Creswell, 2012; Spradley \& McCurdy, 2012). Aspek yang dipelajari dalam budaya adalah: kebiasaan (cultural behaviour), pengetahuan (cultural knowledge), dan artefak kebudayaan (cultural artefact) (Spradley, 1980).

Cakupan penelitian etnografi dapat meliputi bahasa, ritual, struktur ekonomi dan politik, panggung kehidupan, interaksi masyarakat dan cara mereka berkomunikasi. Mengikuti Creswell (2012), untuk mendapatkan data-data lapangan peneliti etnografi ini sebagian besar melalui wawancara, pengamatan, dan penelitian dokumen terkait kelompok masyarakat yang sedang diteliti (Hindu Bali). Analisis data dilakukan dengan metode Spradley (1980) yaitu analisis domain, analisis taksonomi, analisis komponen, dan analisi tema. Sedangkan untuk mencapai validitas data dilakukan dengan triangulasi, yaitu membandingkan data dari sumber yang berbeda-beda..

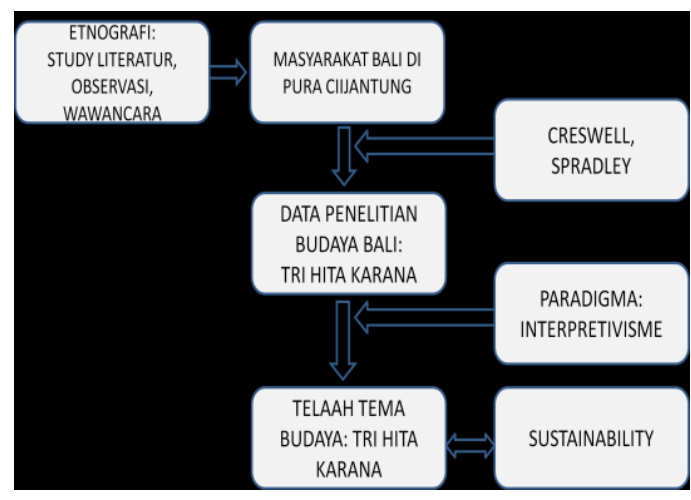

Gambar 2 Skema Penelitian Budaya dengan Etnografi, Sumber: diolah sendiri. 


\section{Situs penelitian}

Penelitian ini dilakukan dengan subyek masyarakat Bali. Tempat yang dipilih adalah Pura Mustika Dharma Cijantung, dimana salah seorang peneliti (Nyoman) merupakan insider masyarakat dalam Pura tersebut. Setiap pura Hindu Bali adalah identik, sehingga keadaan di lokasi penelitian dapat mewakili keseluruhan masyarakat Bali dalam konteks pengamalan Tri Hita Karana.

\section{Instrumen dan informan penelitian}

Peneliti merupakan instrumen penelitian yang terlibat aktif dalam interaksi dengan masyarakat tineliti. Salah satu peneliti merupakan insider masyarakat Bali, yang mengalami langsung pengalaman sosial masyarakat Bali dalam jangka waktu yang cukup lama.

Peneliti secara cermat memilih individu dan tempat untuk mempelajari atau memahami fokus permasalahan. Pedoman yang digunakan untuk memilih partisipan dan tempat adalah apakah mereka "kaya informasi" (Patton, 1990 dalam Creswell, 2012) serta memenuhi lima kriteria (enkulturasi penuh, keterlibatan langsung, suasana budaya yang tidak dikenal, waktu yang cukup, dan non analitis) yang dianjurkan oleh Spradley (1979). Informan dipilih langsung saat mengunjungi situs penelitian. Wawancara dilakukan setelah peneliti memperkenalkan diri dan mengutarakan maksud penelitian. Wawancara dilakukan jika informan tersebut setuju dan memahami tema yang sedang diteliti yaitu Tri Hita Karana.

\section{HASIL DAN PEMBAHASAN}

\author{
Konsep Tri Hita Karana, Respon \\ Berbasis Kearifan Lokal
}

Tri Hita Karana (THK) adalah sebuah konsep yang hidup dan dilakoni kalangan masyarakat Bali. Tri Hita Karana berasal dari kata Tri yang artinya tiga sedangkan Hita artinya kebahagiaan dan Karana yang berarti penyebab. Secara keseluruhan Tri Hita Karana dapat diartikan tiga penyebab terwujudnya kebahagiaan. Kebahagiaan yang dimaksud adalah kebahagian secara lahir dan bhatin. Menurut Palguna (2011) bahwa Hita berarti harmonis, Karana berarti sebab, jadi Tri Hita Karana berarti tiga sebab terjadinya keharmonisan. Filosofi Tri Hita Karana merupakan ajaran kearifan lokal yang tumbuh dan berkembang dijadikan landasan oleh masyarakat keturunan dari Bali untuk menjalani kehidupan yang harmonis diantara keberagaman suku, budaya, dan agama di Indonesia. Keharmonisan yang dimaksudkan adalah keharmonisan atau keselarasan kepada Tuhan Yang Maha Esa, sesama manusia dan terhadap lingkungan alam semesta (tumbuhan, hewan, bangunan tempat umum, aliran air, dan lain-lain). Ketiga titik tersebut saling berkaitan antara satu dengan yang lainnya, diamalkan secara simultan dan benar untuk tercapainya tujuan hidup yaitu kebahagiaan lahir dan bhatin. THK merupakan sebuah filosofi sekaligus telah menjadi way of life masyarakat Bali dalam segala aspek kehidupan (Riana, 2011). Pimpinan pura yang menjadi informan penelitian juga memberikan keterangan yang sama.

Informan penelitian memaparkan, THK terdiri dari tiga dimensi yaitu: parahyangan (keharmonisan manusia dengan Tuhan), pawongan (keharmonisan sesama manusia), dan palemahan (keharmonisan manusia dengan alam semesta atau lingkungan sekitar). Adapun uraian dari tiga dimensi THK adalah sebagai berikut: 
Parahyanyan (keharmonisan manusia kehadapan Tuhan Yang Maha Esa) Artinya segala upaya yang dilakukan oleh manusia dengan cara yang baik untuk tercapainya keharmonisan antara manusia dengan Tuhan Yang Maha Esa. Upaya atau usaha yang dilakukan oleh manusia untuk mendekatkan diri kepada Tuhan Yang Maha Esa tentunya mengedepankan prinsip-prinsip prikemanusiaan, dengan rasa saling menghormati dan menghargai sesama manusia sebagai ciptaan Tuhan. Mengarah yang lebih spesifik lagi yaitu menjalankan ajaran kebaikan dari agama dengan mementingkan perdamaian antar sesama manusia di dunia.

Pawongan (keharmonisan antara sesama manusia) artinya segala upaya yang dilakukan oleh manusia dengan cara-cara yang baik untuk mewujudkan keharmonisan antara sesama manusia di Indonesia khususnya di Bali. Segala upaya yang dimaksud juga memperhatikan pri kemanusiaan, saling menghormati antar sesama manusia walaupun terdapat bermacam macam perbedaan, saling menghargai sesama manusia. Selain itu dapat juga dilakukan dengan saling tolong menolong dengan tujuan menciptakan perdamaian dan kesejahteraan sesama manusia. Perdamaian sangat berkaitan erat dengan perekonomian Negara Indonesia, maksudnya adalah ketika perekonomian Negara Indonesia tumbuh maka dipengaruhi oleh perdamaian bangsa Indonesia dan juga sebaliknya. Walaupun kenyataannya kita hidup penuh dengan perbedaan tetapi pada intinya Tuhan menciptakan perbedaan agar saling mengenal, saling tolong menolong sehingga bagaikan haparan pelangi di sore hari yang kelihatan sangat indah jika mata memandang karena perpaduan bermacam- macam warna.

Palemahan (menjaga keharmonisan dengan alam atau lingkungan hidup) artinya segala upaya manusia dengan cara-cara yang baik untuk mewujudkan keharmonisan dengan alam semesta beserta isinya, dengan tidak bertentangan dengan norma, udangundang, adat istiadat dan ajaran agama. Menjaga dan melestarikan lingkungan merupakan tugas dan tanggung jawab manusia agar dapat hidup dengan tentram, aman dan damai. Keterkaitan Palemahan dengan pelestarian lingkungan yaitu adanya kesamaan cara melestarikan alam semesta.

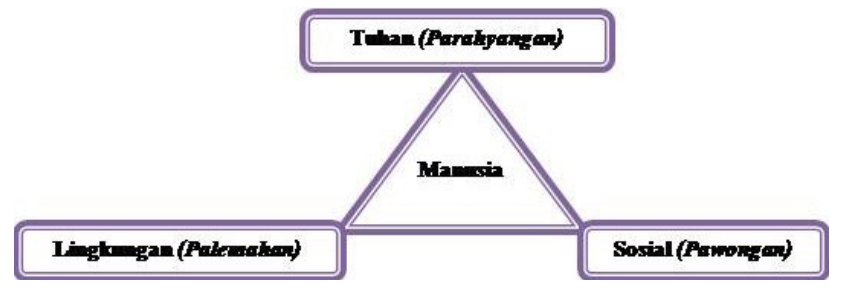

Gambar 3. Hubungan Garis Segitiga Tri Hita Karana, Sumber: diolah sendiri.

\section{Tri Hita Karana dalam Kehidupan Masyarakat Bali}

Cara pandang (way of life) orang Bali dapat dilihat dari artefak-artefak budayanya. Ciri-ciri khas bangunan arsitektur Bali menggambarkan keseimbangan (harmoni) dengan alam sekitar. Ketika peneliti berkunjung ke situs penelitian yakni Pura Mustika Dharma Cijantung, sangat terasa suasana asri yang melingkupi. Pohon-pohon 
tumbuh rindang, kicau burung dan gemercik air terdengar di sekitar Pura. Beberapa pohon dan patung dibaluti dengan kain berpola kotak catur hitam putih (kain poleng). Suasana tidak terlalu ramai dan juga tidak sepi. Kehangatan dan kedamaian akan segera menghampiri siapa saja yang mengunjunginya. Begitulah hidup orang Bali, mengutamakan keseimbangan.

Bangunan Pura dibagi dalam tiga bagian utama: utama mandala merupakan bagian dengan posisi paling tinggi, setelah itu madya mandala dan paling rendah nista mandala. Utama mandala berfungsi sebagai tempat sembahyang dan pelaksanaan upacara keagamaan. Madya mandala merupakan tempat kegiatan warga seperti pementasan seni, belajar bersama atau melakukan pertemuan-pertemuan. Kemudian nista mandala adalah pekarangan yang dapat dipergunakan untuk bermacam kegiatan seperti olahraga dan hiburan.

Orang Bali memandang alam semesta dengan segala isinya sebagai ciptaan Tuhan yang diberikan sebagai karunia kepada manusia untuk dimanfaatkan dalam kehidupannya dengan cara yang wajar dan tidak berlebihan (palemahan). Dalam wawancara dengan seorang informan di pelataran Pura Mustika Dharma Cijantung, ketika peneliti bertanya tentang pohon yang dililiti dengan kain poleng itu, informan menyampaikan bahwa dalam pandangan orang Bali pemberian kain itu adalah simbol penyucian kepada tempat itu. "Kalau ada air, ada pohon besar disana, orang Bali menyucikan tempat itu. Setelah tempat itu disucikan, maka orang tidak akan menebang pohon itu, tidak berani kencing disitu" demikian informan menerangkan makna pemberian kain pada pohon dalam budaya Bali.
Aplikasi lain dari palemahan adalah menanam pohon dan terasering atau sengkedan yakni menanam pohon pada lahan-lahan yang miring. Saat peneliti mengunjungi Pura Mustika Dharma Cijantung, terlihat warga Bali sedang membersihkan pekarangan pura, tak lama kemudian ada sekelompok ibu yang datang menyiapkan makanan bagi mereka. Kami memperkenalkan diri, menyampaikan maksud kami untuk mengetahui Tri Hita Karana dan kemudian berbincang-bincang dengan ibu itu, menanyakan pandangan mereka tentang Tri Hita Karana. "Ini merupakan pengamalan Tri Hita Karana" kata ibu itu sambil mengarahkan pandangannya kepada warga yang sedang membersihkan pekarangan pura. "Kami ibu-ibu membantu menyediakan makan ini" lanjutnya. Informan tersebut bercerita tentang kerusakan alam dan merosotnya budi pekerti saat ini. Kebakaran hutan yang menyebabkan bencana asap serta punahnya biota hutan, kemarau panjang yang menyebabkan kekeringan, dan banjir yang melanda ketika musim penghujan tiba. Semuanya kesukaran itu timbul sebagai akibat dari hilangnya keseimbangan, hilangnya harmoni dari kehidupan umat manusia. Dari perbincangan kami dengan informan tersebut dapat disarikan beberapa sikap orang Bali dalam pengamalan Tri Hita Karana.

Tentang palemahan, informan menerangkan lebih lanjut sebagai berikut: "Alam harus dibina, tidak boleh dirusak atau dibakar. Pohon dan binatang memiliki upacara tersendiri dalam Hindu Bali, tidak hanya menghargai dengan upacara yadnya (upacara persembahan suci yang tulus ikhlas ke hadapan unsur-unsur alam) tetapi pemeliharaan alam harus dilaksanakan setiap hari sebagai perwujudan Tri Hita Karana. Menikmati alam hanya secukupnya. Ada upara khusus untuk menghormati tumbuh- 
tumbuhan yang dilakukan setiap tujuh bulan dengan harapan beliau (tumbuhan) bersahabat dengan manusia... Palemahan dipraktekkan mulai dari rumah tangga dengan menanam pepohonan, tidak ada rumah yang gersang".

Tentang pawongan, informan menyampaikan sebagai berikut: "Hubungan dengan manusia diamalkan dengan prinsip "aku adalah kamu, kamu adalah aku". Manusia selayaknya tidak saling menyakiti, sedangkan binatang sekalipun tidak boleh disakiti. Pawongan mengatur hubungan bermasyarakat seperti krama desa adat.

Parahyangan diamalkan dengan selalu berada di jalan Tuhan, menjauhi laranganNya dan bersembahyang untuk menyampaikan syukur kepadaNya. Seorang informan peneliti di lokasi Pura menyampaikan bahwa setiap upacara (sembahyang) kepada Tuhan selalu menggunakan sesuatu yang bersumber dari alam seperti air, kembang, dupa. Itu semua melambangkan bahwa hubungan dengan Tuhan juga harus dilakukan dengan melestarikan alam.

Bali sejak lama sudah mempraktikkan pengelolaan alam yang seimbang, contohnya adalah subak. Subak merupakan salah satu manifestasi filosofi Tri Hita Karana yaitu sebuah sistem pembagian ari untuk persawahan, pura, dan masyarakat. Air dikelola sedemikian rupa sehingga tetap dapat lestari, sehat dan tersedia untuk semua.

United Nations Educational, Scientific and Cultural Organization (UNESCO) telah menetapkan subak sebagai warisan dunia pada 29 Juni 2012. Pengakuan itu diperoleh setelah melalui tahapan panjang selama 12 tahun. Dari 26 negara yang mendaftarkan local wisdom-nya, Indonesia melalui subak di Bali mendapat pengakuan dunia. Bahwa kearifan lokal Indonesia bernama subak sebagai manifestasi dari Tri Hita Karana telah berhasil menjaga kelestarian alam di Bali. Subak diharapkan dapat menjadi konsep pembangunan berkelanjutan.

\section{SIMPULAN DAN SARAN}

\section{Refleksi Penelitian}

Kerusakan alam merupakan kenyataan yang dihadapi oleh umat manusia saat ini. Daya upaya yang dilakukan menurut hukum rasionalitas, yang semula diniatkan untuk memudahkan umat manusia dalam memenuhi kebutuhan hidupnya ternyata berdampak sebaliknya bagi kehidupan. Alam saat ini dalam kondisi yang tidak seimbang. Telah terjadi eksploitasi berlebihan teradap alam. Manusia semakin serakah dan dipenuhi semangat materialism. Kondisi sekarang jika dibiarkan berlanjut, maka ada potensi runtuhnya alam dan peradaban manusia. Rasionalitas yang berujung pada irrasionalitas dan mengorbankan sisi kemanusiaan manusia itu sendiri akan menjadi bencana yang lebih besar. Masyarakat akuntansi yang terjebak dalam arus materialism masuk di dalam jaringan yang mengeksploitasi alam secara berlebihan.

Manusia menyadari kemerosotan tersebut. Dilakukan upaya pencegahan kerusakan alam dengan memikirkan ulang cara mencapai tujuan manusia. Kelestarian alam menjadi hal yang menarik perhatian manusia saat ini. Gerakan pelestarian lingkungan mengemuka seperti Green Peace. Entitas bisnis yang hidup dari semangat kapitalisme pasar bebas kini beramairamai menggaungkan gerakan penyelamatan lingkungan.

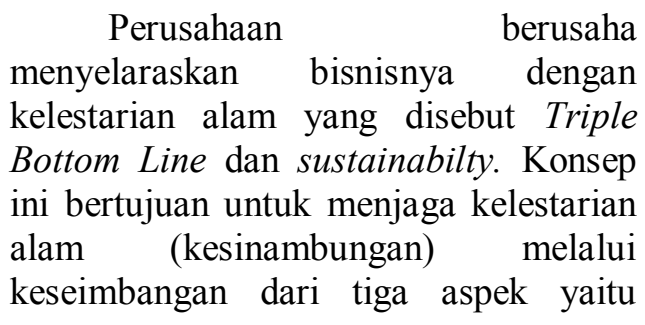


manusia (people), lingkungan (planet), dan laba (profit). Keberhasilan sebuah entitas bisnis tidak lagi didasarkan pada laba akuntansi semata, tetapi juga didasarkan pada kemampuan perusahaan tersebut menjaga lingkungan alam dan memberikan kontribusi positif kepada manusia di sekitarnya.

Indonesia sendiri, pada dirinya sudah ada nilai atau kearifan lokal (local wisdom) diantaranya Tri Hita Karana (THK) dari budaya Hindu Bali. THK memusatkan keseimbangannya pada keharmonisan hubungan manusia dengan Tuhan (parahyangan), keharmonisan hubungan manusia dengan manusia (pawongan), serta keharmonisan hubungan manusia dengan alam (palemahan). Untuk mencapai kebahagian yang sesungguhnya, manusia harus hidup dalam keharmonisan. Dalam konsep ini, laba bukanlah tujuan tetapi akibat (ganjaran) dari sebuah laku hidup yang seimbang. THK merupakan produk dari pemahaman (verstehen) akan hakikat kemanusiaan (human nature) dan pengakuan akan kuasa Tuhan.

Masyarakat Bali dengan simbolsimbol kebudayaannya telah membuktikan bahwa keharmonisan hubungan manusia dengan Tuhannya, manusia dengan sesamanya, serta manusia dengan alam menjadi kunci kesinambungan masyarakat Bali di mana pun berada. Pulau Bali yang terbuka bagi dunia dan menjadi destinasi wisata termasyur di dunia, dengan konsekuensi masuknya budaya asing dari luar, terbukti sampai hari ini masih dapat melestarikan lingkungan dan kebudayaannya. Keharmonisan hubungan tersebut diyakini dapat menjaga kesinambungan kehidupan umat manusia di bumi (sustainability).

Masyrakat dunia pun melalui UNESCO telah mengakui subak sebagai warisan dunia yang harus dilestarikan.
Subak merupakan salah satu manifestasi filosofis dari Tri Hita Karana, terbukti dan diyakini dapat menjaga keseimbangan dan kelestarian alam. Pengakuan dunia tersebut seharusnya membawa kesadaran baru bagi bangsa Indonesia bahwa konsep-konsep lokal Indonesia sesungguhnya telah teruji. Sehingga dapat pula diterapkan dalam dunia usaha.

\section{Keterbatasan Penelitian}

Bali dan budayanya memiliki banyak simbol-simbol budaya. Baik melalui seni maupun upacara-upacara adat (agama) yang dijalankan. Meskipun salah satu dari peneliti merupakan insider dan kami sudah melakukan riset lapangan untuk belajar langsung kepada anggota masyarakat Bali, tetapi sumbersumber tersebut dirasa masih terbatas untuk memahami makna-makna dari simbol-simbol budaya tersebut secara mendalam.

Penelitian yang dilakukan di Jakarta menyisakan keterbatasan lain. Walaupun kondisi Pura selalu identik, tetapi alam sekitar (Bali) tidak teramati dengan baik dalam penelitian ini. Peneliti berharap dapat melakukan penelitian lapangan dengan metode "Pengamatan Berperan Serta", langsung di Pulau Bali sehingga dapat menangkap dan memahami lebih dalam makna dari simbol-simbol budaya Bali.

\section{Saran Penelitian}

Penelitian ini dapat menjadi pemicu (trigger) kepada masyarakat bisnis Indonesia untuk menggali dan mengadopsi nilai-nilai kearifan lokal ke dalam kebijakan perusahaan. Memasukkan nilai-nilai budaya lokal dalam kebijakan perusahaan untuk mencapai keharmonisan dan keberlangsungan kehidupan umat manusia di bumi.

Tri Hita Karana sebagai bagian daripada adat terbukti dapat menjaga 
kelestarian alam dan budaya Bali, jika diamalkan dalam hukum positif berpotensi mengembalikan manusia kepada kelestarian kemanusiaan. Sukusuku di Indonesia tidak lepas daripada adat istiadat sebagai bagian dari budayanya. Sustainability dapat dicapai dengan kembali kepada adat istiadat orang Indonesia sendiri. 


\section{DAFTAR PUSTAKA}

Arya, I. M. U. 2008. Revitalisasi Tri Hita Karana dalam Melindungi Lingkungan Hidup di Bali. Majalah Media Hindu.

Beck, U. 2000. What Is Globlaization?. Polity Press.

Boden, D. 1990. People Are Talking: Conversation Analysis and Symbolic Interaction. Dalam Howard S. Becker and Michal M. McCall (Editors), Symbolic Interaction and Cultural Studies (hlm 244274). London: The University of Chicago Press.

Burrel, G. and Morgan G. 1979. Sociological Paradigms and Organizational Analysis. London: Heinemann Educational Books.

Creswell, J. W. 2012. Educational Research: Planning, Conducting, and Evaluating Quantitative and Qualitative Research (Fourth Edition). USA: Pearson.

Denzin, N. K., and Lincoln, Y. S. (Editors). 2005. The Sage Handbook of Qualitative Research, (Third Edition). London: Sage Publication.

Denzin, N. K. (1992. Symbolic Interactionism and Cultural Studies: The Politics of Interpretation, USA: Blackwell.

Edwards, T., (Editor). 2007. Cultural Theory, London: Sage Publications

Elkington, J. 1997. Cannibal with Forks : The Triple Bottom Line of $21^{\text {st }} \quad$ Century Business.
Oxforf, UK: Capstone Publishing.

Geertz, C. 1973. The Interpretation of Cultures. New York: Basic Books Publishers.

Gede, I. R. 2011. Dampak Penerapan Kultur Lokal Tri Hita Karana terhadap Orientasi Kewirausahaan dan Orientasi Pasar. Jurnal Teknik Industri, Vol. 13.

Giddens, A. 2009. Sociology. United Kingdom: Polity Press, Cambridge.

Ihromi, T.O., (Editor). 1996. PokokPokok Antropologi Budaya. Jakarta: Yayasan Obor Indonesia.

Kamayanti, A. 2015. "Sains" Memasak Akuntansi: Pemikiran Udayana dan Tri Hita Karana, Jurnal Riset dan Aplikasi: Akuntansi dan Manajemen, Vol. 1, No. 2.

Kuntjaraningrat. 2005. Pengantar Antropologi: Pokok-pokok Etnografi II. Rineka Cipta.

Kuntowijoyo. 2006. Budaya dan Masyarakat (Edisi Paripurna). Yogyakarta: Tiara Wacana.

Kurniawan, R., Mulawarman, A. D., Kamayanti, A. 2014. Biological Assets Valuation Reconstruction: A Critical Study of IAS 41 on Agricultural Accounting in Indonesia Farmers, International Conference on Accounting Studies 2014, Malaysia. Elsevier.

Lutfillah, N. Q. and Sukoharsono, E. G. 2013. Historiografi Akuntansi Indonesia Masa Mataram Kuno (Abad VII-XI 
Masehi), Jurnal Akuntansi Multiparadigma, Vol. 1, Nomor 1. Malang.

Malinowski, B. 1960. A Scientific Theory of Culture and Other Essays. New York: A Galaxy Book, Oxford University Press.

Mulawarman, A. D. 2010. Integrasi Paradigma Akuntansi: Refleksi atas Pendekatan Sosiologi dalam Ilmu Akuntansi, Jurnal Akuntansi Multiparadigma Vol. 1 No. 1 April 2010. Malang: Universitas Brawijaya.

Nainggolan, T. 2014. Batak Toba: Sejarah dan Transformasi Religi. Medan: Bina Media Perintis.

Palguna, D. I. B. M. 2011. Leksikon Hindu. Jakarta: CV Zalfindo Perdana.

Ritzer, G. \& Goodman, D. J. (2008). Teori Sosiologi Modern. Jakarta: Kencana.

Salim, A. 2006. Teori dan Paradigma Penelitian Sosial: Buku Sumber untuk Penelitian Kualitatif. Yogyakarta: Tiara Wacana.

Sitorus, F. M. T. 2015. Monografi Penelitian Kualitatif. Jakarta: Tidak Diterbitkan.

Spradley, J. P. 2007. Metode Etnografi (The Ethnographic Interview), Zulfa Misbah (Penerjemah). Yogyakarta: Tiara Wacana.

Spradley, J. P. and McCurdy, D. W., (Editors). 2012. Conformity and Conflict: Reading in Cultural Anthropology (Fourteenth Edition). New Jersey: Pearson.
Sukoharsono, E. G. 2010. Metamorfosis Akuntansi Sosial dan Lingkungan: Mengkonstruksi Akuntansi Sustainabilitas Berdimensi Spiritulitas. Pidato Pengukuhan Jabatan Guru Besar Dalam Ilmu Akuntansi Sosial dan Lingkungan Fakultas Universitas Brawijaya, Malang.

Swasono, S. E. 2004. Ekspose Ekonomika: Mewaspadai Globalisme dan Pasar Bebas Ekonomi. Yogyakarta: Pusat Studi Ekonomi Pancasila (Pustep) UGM.

Triyuwono, I. 2010. Mata Ketiga: Se Laen Sang Pembebas Sistem Pendidikan Tinggi Akuntansi. Jurnal Akuntansi Multiparadigma, Vol. 1.

Triyuwono, I. 2013. [Makrifat] Metode Penelitian Kualitatif [dan Kuantitatif] untuk Pengembangan Disiplin Akuntansi. Makalah Diseminarkan dalam Simposium Akuntansi Nasional ke-16, Manado.

Willis, J. W. 2007. Foundation of Qualitative Research: Interpretive and Critical Approaches. USA: Sage Publications.

Wolff, K. H. (Editor). 1950. The Sociology of Georg Simmel. The Metropolis and Mental Life. Illionis: The Free Press.

National Geographic. 2012. Plakat UNESCO, Pengakuan Subak Sebagai Warisan Dunia 2012. Diunduh pada tanggal 1 Februari 2016.. 
Jurnal Manajemen Hasil Penelitian

Vol.13(2) : 85-191 Th. 2017

ISSN: 1907-0896 